\title{
DETECTION OF PORK CONTAMINATION IN FRESH AND COOKED BEEF USING GENETIC MARKER MITOCHONDRIAL-DNA CYTOCHROME B BY DUPLEX-PCR
}

\author{
A. Ni'mah, Y. Kartikasari, A. D. Pratama, L. R. Kartikasari, B. S. Hertanto and M. Cahyadi \\ Department of Animal Science, Faculty of Agriculture, Sebelas Maret University, \\ Jl. Ir. Sutami 36A Surakarta 57126 - Indonesia \\ Corresponding E-mail: mcahyadi@uns.ac.id
}

Received November 30, 2015; Accepted February 13, 2016

\begin{abstract}
ABSTRAK
Pemalsuan daging sapi yang dicampur dengan daging babi merupakan salah-satu permasalahan umat Muslim yang sering ditemukan di Indonesia. Penelitian ini bertujuan untuk mendeteksi daging babi pada daging sapi segar dan masak menggunakan marker genetik DNA mitokondria gen Cytochrome $b$ (mt-DNA Cyt b) dengan duplex-PCR. Penelitian ini menggunakan 6 sampel daging segar dan 6 sampel daging yang dimasak. Sampel daging babi diperoleh dari Rumah Potong Babi (RPB), sedangkan sampel daging sapi dibeli dari supermarket di Kota Surakarta. Sampel daging masak disiapkan dengan cara merebus daging pada suhu $100^{\circ} \mathrm{C}$ selama 30 menit. Kontaminasi daging babi pada daging sapi segar maupun masak dirancang sebesar $0,1,5,10$, dan $25 \%$. Selanjutnya, total DNA diisolasi dari sampel tersebut dan polymerase chain reaction (PCR) dilakukan menggunakan primer spesifik untuk mengamflifikasi fragmen spesifik masing-masing spesies. Hasil penelitian menunjukkan bahwa total DNA berhasil diekstraksi dari sampel daging sapi, daging babi, dan campuran keduanya baik pada sampel daging segar maupun masak. Selanjutnya, elektroforesis pada agarosa $1,5 \%$ menunjukkan bahwa duplex-PCR mt-DNA Cyt $b$ berhasil mendeteksi kontaminasi daging babi pada daging sapi segar maupun masak hingga level $1 \%$. Keberadaan daging babi pada sampel ditunjukkan dengan adanya pita DNA sebesar 398 bp. Kesimpulan penelitian ini adalah duplex-PCR mt-DNA Cyt b sangat sensitif dalam mendeteksi cemaran daging babi pada daging sapi segar maupun masak.
\end{abstract}

Kata kunci: cytochrome b, daging babi, daging sapi, duplex-PCR, kontaminasi

\begin{abstract}
By mixing with pork, beef adulteration is frequently found in the traditional market that very disturbing Moeslem community in Indonesia. This study was conducted to detect pork contamination in fresh and cooked beef using genetic marker mitochondrial DNA cytochrome b (mt-DNA Cyt b) by duplex-PCR. A total of twelve samples was used in this study consisting six fresh meat samples and six cooked meat samples, respectively. Those beef and pork were bought from animal slaughterhouse and a supermarket in Surakarta. Cooked samples were prepared by boiling the meats in hot water at $100^{\circ} \mathrm{C}$ for 30 minutes. We designed pork contamination in beef in the level of $0,1,5,10,25 \%$, respectively. The DNA genome was extracted and polymerase chain reaction (PCR) was performed using species specific primer to isolate mt-DNA Cyt b gene from the samples. The results showed that the DNA genome was successfully extracted from pork, beef, and contaminated meat samples. In addition, visualization of duplex-PCR on $1.5 \%$ agarose gel was able to detect pork contamination in both fresh and cooked beef up to very small proportion (1\%). The existence of pork in beef was indicated with the presence of specific 398 bp DNA band. It can be concluded, duplex-PCR of mt-DNA Cyt b gene was very sensitive in detection of pork contamination in fresh and cooked beef.

Keywords: beef, contamination, cytochrome b, duplex-PCR, pork
\end{abstract}




\section{INTRODUCTION}

The awareness of Indonesian to the need of animal protein resources such as beef has steadily been increased recently, however, the beef price is highly expensive in Indonesia. On the other hand, pork is one of cheap animal protein resources than can be found easily in the market. These conditions open an opportunity for some peoples to achieve more profits by mixing beef with pork. Due to cheaper in price and relatively similar characteristics, pork is commonly used for beef adulteration. Previous study reported by Ali et al. (2012) revealed that contamination of pork in beef and processed-beef products has been found and widely spread in the capital city in Indonesia.

Islam is the major religion in Indonesia, therefore, utilization of pork and pork derivates are prohibited especially in food for Moslem consumer (Said et al., 2011). According to Islam point of view, pig is one of haram thing that clearly described in holy Al-Qur'an surah AlBaqarah verse number 173. Therefore, scientific approach is urgently needed to detect contamination of pork and pork derivate to protect Muslim consumer in Indonesia from undesired components in food, especially in beef.

The effort to detect pork contamination in beef has been developed since decades ago. Polymerase chain reaction (PCR) is one of molecular biology approaches which is used to authenticate and to detect species origin in meat by amplifying species specific sequence in the genome such as fragment of mt-DNA Cyt $b$ gene (Girish et al., 2005). Cyt b gene is a gene that frequently used for phylogenetic studies. The primer of Cyt b gene has been designed to amplify specific site for various species for example mammals, birds, amphibian, reptile, fish, insects, and spider (Kocher et al., 1989).

Species detection in meat based on deoxyribonucleic acid (DNA) using PCR has successfully been performed to identify DNA originated from fresh meat and processed meat products (Aida et al., 2005). Multiplex-PCR, a variant of PCR approaches that often used for species authentication, is a molecular technique consisted of two or more loci which is simultaneously performed in one PCR reaction. This method has often been applied to analyze DNA deletion, mutation, and polymorphism (Henegariu et al., 1997). Matsunaga et al. (1999) reported that multiplex-PCR has succesfully been applied for species identification in raw and cooked meats. In Indonesia, the use of mt-DNA Cyt $b$ gen to detect species origin in raw meat and meat products has been done. Nuraini et al. (2012) and Irine et al. (2013) reported that dog, cat, tiger, and rat can be detected using partial sequence of mt-DNA Cyt $b$ gene as a biomarker. Here, we performed both simplex-PCR and duplex-PCR to amplify two target fragments from beef and pork samples. Therefore, the aim of this study was to detect pork contamination in fresh and cooked beef using genetic marker mt-DNA Cyt $b$ by duplex-PCR.

\section{MATERIALS AND METHODS}

\section{Samples Preparation}

Both pork and beef samples were obtained from commercial sources. The meats samples were labeled to make sure that all samples were separated each other and then all meats were stored in the refrigerator until used. Beef samples were contaminated with pork in the ratio 100:0, $75: 25,90: 10,95: 5$, and $0: 100 \%$ (beef:pork). Those rations were also applied for cooked samples. For cooked meats, $1000 \mathrm{mg}$ samples were prepared and boiled in water at $100^{\circ} \mathrm{C}$ for 30 minutes.

\section{Extraction of DNA}

The DNA genome was prepared from cattle and pig by following Genomic DNA Mini Kit for animal tissue protocol (Geneaid Biotech Ltd., Taiwan). A total of $30 \mathrm{mg}$ meat tissue was weighed and transferred to a $1.5 \mathrm{~mL}$ microcentrifuge tube, and then the meat was grinded to a pulp using micropestle provided by the kit. Total of $200 \mu \mathrm{L}$ of GT buffer was added to the tube and homogenized by grinding. Then, 20 $\mu \mathrm{L}$ of proteinase $\mathrm{K}$ was also added to the mixture and then the mixture was incubated at $60^{\circ} \mathrm{C}$ for 30 minutes. Furthermore, $200 \mu \mathrm{L}$ of GBT buffer was added into the tube and incubated at $60^{\circ} \mathrm{C}$ for at least 20 minutes to ensure the lysate is clear. For the next step, $200 \mu \mathrm{L}$ of absolute ethanol was added to the lysate then immediately shaken vigorously for 10 seconds. The mixture was transferred to the GD column placed in a $2 \mathrm{~mL}$ collection tube and it was centrifuged at 14.000 rpm for 2 minutes. After that, $2 \mathrm{~mL}$ collection tube was discarded and the GD column was transferred to a new $2 \mathrm{~mL}$ collection tube. Furthermore, $400 \mu \mathrm{L}$ of $\mathrm{W} 1$ buffer was added to the GD column and centrifuged at $14.000 \mathrm{rpm}$ for 
30 seconds, and then the flow-through in the $2 \mathrm{~mL}$ collection tube was discarded. The GD column was placed back in the $2 \mathrm{~mL}$ collection tube and added $600 \mu \mathrm{L}$ of wash buffer to the GD column for centrifugation at $14.000 \mathrm{rpm}$ for 30 seconds. The flow-through was discarded and then GD column was placed back in the $2 \mathrm{~mL}$ collection tube for final centrifugation at $14.000 \mathrm{rpm}$ for 3 minutes to dry the column matrix. In addition, dried GD column was transferred to a clean 1.5 $\mathrm{mL}$ microcentrifuge tube and then $100 \mu \mathrm{L}$ of preheated elution buffer was added to the center of the column matrix until completely absorbed. The final step, the mixture was centrifuged at 14.000 rpm for 30 second to elute the purified DNA. Then, the DNA genome was visualized by $1 \%$ electrophoresis agarose gel using Gel Document (Vilber Lourmat Infinity 1100126M, France) and it is ready to be used for next analysis.

\section{Simplex- and duplex-PCR}

The PCR amplification was conducted in total volume of $25 \mu \mathrm{L}$ containing $12.5 \mu \mathrm{L} 2 \mathrm{X}$ KAPA2G Fast Multiplex Mix (Kapa Biosystems, Inc., United States), $0,5 \mu \mathrm{L}$ each primer $(10 \mu \mathrm{M})$, $1 \mu \mathrm{L}$ DNA template, and $\mathrm{ddH}_{2} \mathrm{O}$. To isolate DNA target, three primers which are designed by Matsunaga et al. (1999) were used in this study. Those primers were universal forward primer (5'GACCTCCCAGCTCCATCAAACATCTCATCT TGATGAAA-3') and reverse primers for bovine (5'-CTAGAAAAGTGTAAGACCCGTAATATAA G3'), and reverse primer for pig (5'GCTGATAGTAGATTTGTGATGACCGTA-3').

The PCR reaction was carried out using GeneAmp ${ }^{\circledR}$ PCR System 9700 (Singapore) as follows: initial denaturation at $95^{\circ} \mathrm{C}$ for 3 minutes, and folled by 30 cycles of denaturation at $95^{\circ} \mathrm{C}$ for 15 seconds, annealing at $60^{\circ} \mathrm{C}$ for 30 seconds, extension at $72^{\circ} \mathrm{C}$ for 30 seconds. To make sure that PCR reaction completed, final extension was applied at $72^{\circ} \mathrm{C}$ for 1 minute. The simplex- and duplex-PCR were viewed in the agarose gel 1.5\% under the UV light using Gel Document (Vilber Lourmat Infinity 1100126M, France).

\section{RESULTS AND DISCUSSION}

\section{The DNA Extraction}

Pork and beef samples were bought from animal slaughterhouse and supermarket in Surakarta, Central Java. A total of 12 samples was designed and used for DNA isolation in this study. In particular, they were six raw meat samples and six cooked meat samples, respectively. The pork contamination in the beef samples was designed as much as $0,1,5,10$, and $25 \%$. The result showed that DNA genome was successfully extracted from both raw meat and cooked meat samples (Figure 1). The principle of genome isolation is extracted the DNA genome from other components of the cells (Muladno, 2012). The cooked meat samples were also obtained. The treatment to the meats did not affect the extraction of DNA genome. Previous studies reported that DNA genome can be extracted from cooked meats such as sausages, cold cut and leisure meat food (Hou et al., 2015; Matsunaga et al., 1999; Nakyinsige et al., 2012; Zhang, 2013). However, the quality of DNA genome isolated from raw meats was better than DNA genome isolated from cooked meats. Figure 1 presents the intencity of the DNA genome isolated from raw meat was clearer than cooked meats under the UV light. Andree et al. (2004) reported that heat and physical treatments on the meat prducts can decrease the quality of DNA genome.

\section{Detection of Pork Contamination in Raw and Cooked Beef}

Both simplex- and duplex-PCR were conducted in this study. Simplex-PCR was applied to optimize the PCR conditions whereas duplex PCR was carried out to detect pork contamination in raw and cooked meats. The existence of pork in the sample mixtures was indicated by 398 bp of mt-DNA Cyt b. This DNA band is specific for porcine. On the other hand, the exsistence of bovine species in the meat mixture was indicated by appearance of $274 \mathrm{bp}$ of specific mt-DNA Cyt b site for bovine. The results

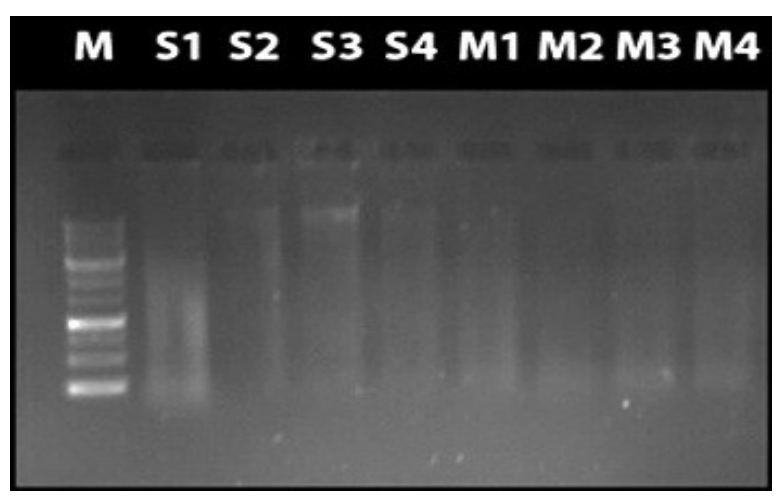

Figure 1. The DNA Genome Extracted from Fresh and Cooked Meats Visualized in 1\% Agarose Gel 


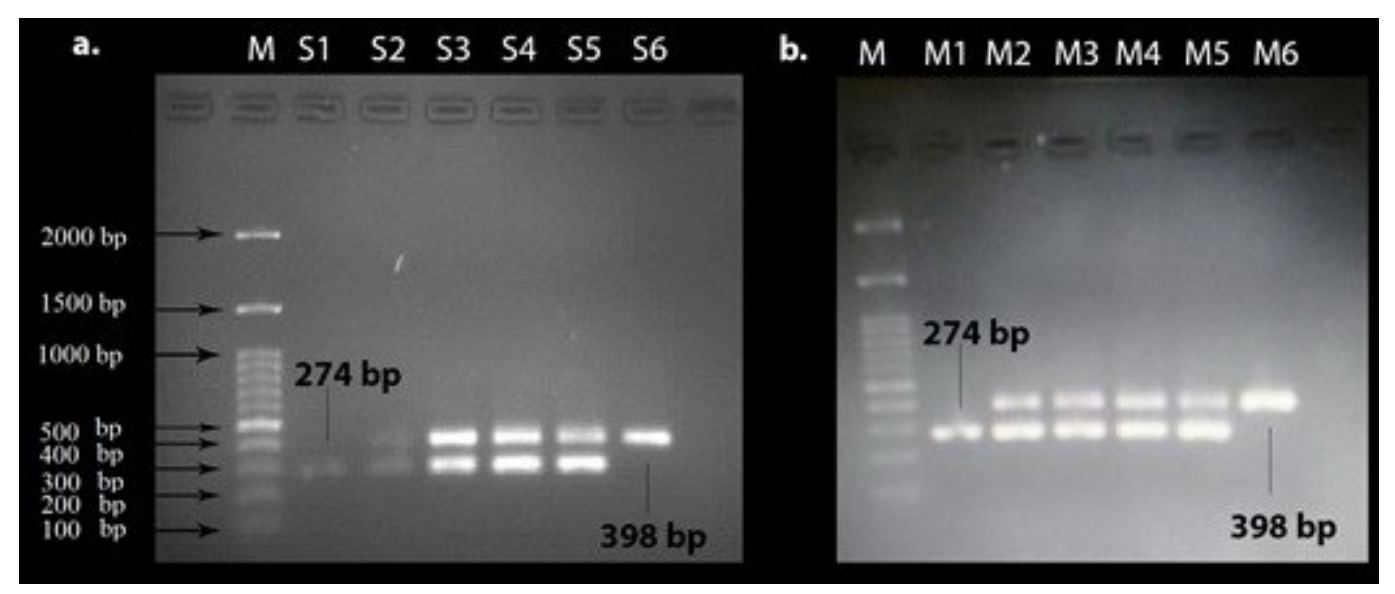

Figure 2. The results of duplex-PCR of mt-DNA Cyt b. Figure $2 \mathrm{a}$ is duplex-PCR of fresh meats, $\mathrm{M}$ is $100 \mathrm{bp}$ marker ladder, $\mathrm{S} 1$ is $100 \%$ raw beef, S2 to S5 are beef samples contaminated with $25,10,5,1 \%$ pork, and S6 is $100 \%$ pork. Figure $2 \mathrm{~b}$ is duplex-PCR of cooked meats, M is 100 bp marker ladder, M1 is $100 \%$ cooked beef, M2 to M5 are cooked beef contaminated with $25,10,5,1 \%$ pork, and M6 is $100 \%$ cooked pork.

of simplex- and duplex-PCR were presented in Figure 2.

This study was succesfully detected pork contamination in fresh and cooked beef. The contamination of pork in beef products can be detected until 1\% contamination of pork. The treatment to the meat samples was not affected this approach to identify the existence of pork in fresh and cooked beef. Previous study reported that species origin of fresh and cooked meats can be detected by multiplex-PCR of mt-DNA Cyt $b$. Kumar et al. (2015) developed primers of mtDNA Cyt b gene to authenticate chevon meat (Capra hircus) by PCR assay. Furthermore, Matsunaga et al. (1999) reported that species contamination can be detected until $8 \%$ in the mixtures. Ali et al. (2015) developed multiplex PCR assay for the detection of five meat species forbidden in Islamic foods. Their assays have successfully detected existence of five species forbidden in Islamic foods (cat, dog, pig, monkey and rat meats) by designing species-specific primers of mitochondrial ND5, ATPase 6, and cytochrome b genes to amplify 172, 163, 141, 129 and 108 bp DNA fragments from those species, respectively. In Indonesia, Erwanto et al. (2014) found the existence of pork in beef meatballs marketed in Yogyakarta by PCR-RFLP method. Currently, Fang and Zhang (2016) successfully detected the existence of mouse in mutton by using TaqMan real-time PCR. In addition,
Rahman et al. (2014) developed PCR assay for the assessment of dog meat adulteration in meatballs. Kitpipit et al (2014) developed directmultiplex PCR assay for meat species identification in food products. They used mtDNA fragment to amplify specific DNA fragment for pork, lamb/mutton, chicken, ostrich meat, horse meat and beef, respectively. Furthermore, Rojas et al. (2010) reported that polymerase chain reaction assay can be used for verifying the labeling of meat and commercial meat products from game birds. This study amplified specific sequences from the mitochondrial D-loop region.

The molecular biology techniques have been utilized for detection of species origin in the food (Zhang, 2013). In Moslem countries, those assays have currently been applied to verify and to authenticate whether a food product is halal or haram. Van der Spiegel et al. (2012) reported that the global halal market is increasing, therefore, standardization and certification of halal products can use laboratory analysis such as DNA-based assays which are very sensitive to achieve appropriate assurance of halal food products and proper labelling for consumers and buyers.

\section{CONCLUSION}

Duplex-PCR of mt-DNA Cyt b gene was able to detect pork contamination in fresh and cooked beef. It may be applied to authenticate 
commercial meat products marketed in Indonesia.

\section{AKNOWLEDGMENT}

This study was supported by the research grant "Penelitian Disertasi dan Doktor BaruUniversitas Sebelas Maret (PDDB-UNS) (No: 698/UN27/PN/2015), Indonesia.

\section{REFFERENCE}

Aida, A. A., Y. B. Che Man., C. M. V. L. Wong., A. R. Raha and R. Son. 2005. Analysis of raw meats and fats of pigs using polymerase chain reaction for halal authentication. Meat Sci. 69:47-52.

Ali, M. E., U. Hashim., S. Mustafa., Y. B. Che Man and K. L. Foo. 2012. Nanobioprobe for the Determination of Pork Alduteration in Burger Formulations. J. Nanomaterials. 2012: 1-7.

Ali, M. E., M. A. Razzak, S. B. Hamid, M. M. Rahman, M. A. Amin, N. R. Rashid and Asing. 2015. Multiplex PCR assay for the detection of five meat species forbidden in Islamic foods. Food Chem. 177:214-224.

Andree, S., K. Altmann, R. Binke and F. Schwagele. 2004. Animal species identification and quantification in meat and meat products by means of traditional and real-time PCR. Fleischwirtschaft. 85: 96-99

Erwanto, Y., M.Z. Abidin, E.Y.Prasetyo, M. Sugiyono and A. Rohman. 2014. Identification of pork contamination in meatballs of Indonesia local market using Polymerase Chain Reaction-Restriction Fragment Lenght Polimorphysm (PCRRFLP) Analysis. Asian-Australas J. Anim. Sci. 27 (10): 1487-1492.

Fang, X. and C. Zhang. 2016. Detection of adulterated murine components in meat products by TaqMan real-time PCR. Food Chem. 192: 485-490.

Girish, P.S., A. S. R. Anjaneyuhu., K. N. Viswas., B. M. Shivakumar., M Anand., M. Patel and B. Sharma. 2005. Meat spesies identification by polymerase chain reactionrestriction fragmen length polymorphism (PCR-RFLP) of mitochondrial $12 \mathrm{~S}$ rRNA gene. Meat Sci. 70: $107-112$.

Hou, B., X. Meng, L. Zhang, J. Guo, S. Li and H. Jin. 2015. Development of a sensitive and specific multiplex PCR method for the simultaneous detection of chicken, duck and goose DNA in meat products. Meat Sci. 101: 90-94

Irine, H. Nuraini and C. Sumantri. 2013. Species authentication of dog, cat, and tiger using cytochrome b gene. Med. Pet. 36(3):171178.

Kitpipit, T., K. Sittichan and P. Thanakiatkrai. 2014. Direct-multiplex PCR assay for meat species identification in food products. Food Chem. 163: 77-82.

Kocher, T. D., W. K. Thomas., A. Meyer., S. V. Edwards and S. Paabo. 1989. Dinamics evolution of mitochondrial DNA evolution in animals: Amplification and sequencing with conserved primers. PNAS. 86:61966200 .

Kumar, A., R.R Kumar, D.S. Brahma, K.M. Sanjod, P. Gokulakrishnan, K. Dhananjay and S. Deepak. 2015. Authentication of goat (Capra hircus) meat using PCR amplification of mitochondrial cytochrome b gene. Small Ruminant Res. 131:17-20.

Matsunaga, T., K. Chikuni., R. Tanabe., S. Muroya., K. Shibata., J. Yamada and Y. Shinmura. 1999. A quick and simple method for the identification of meat species and meat products by PCR assay. Meat Sci. 51: 143-148.

Nakyinsige, K., Y. B. Man and A. Q. Sazili. 2012. Halal authenticity issues in meat and meat products. Meat Sci. 91(3): 207-214

Nuraini, H., A. Primasari, E. Andreas and C. Sumantri. 2012. The use of cytochrome b gene as a specific marker of the rat meat (Rattus norvegicus) on meat and meat products. Med. Pet. 35(1):15-20.

O'Henegariu, N. A., S. R. Heerema., G. H. Dlouhy., Vance and P. H. Vogt. 1997. Multiplex PCR: Critical parameters and step-by-step protocol. BioTechniques 23: 504-511.

Rahman, M. M., M. E. Ali, S. B. Hamid, S. Mustafa, U. Hashim and U. K. Hanapi. 2014. Polymerase chain reaction assay targeting cytochrome $b$ gene for the detection of dog meat adulteration in meatball formulation. Meat Sci. 97(4):404409

Rojas, M., I. González, M. A. Pavón, N. Pegels, P. E. Hernández, T. García and R. Martín. 2010. Polymerase chain reaction assay for verifying the labeling of meat and commercial meat products from game birds targeting specific sequences from the 
mitochondrial D-loop region. Poult Sci. 89(5):1021-1032.

Said, M. I., J. C. Likadja dan M. Hatta. 2011. Effect of time and curing concentration on quantity and quality of goat skin gelatin produced by acid process. JITP 1:119-128.

Van der Spiegel, M., H. J. van der Fels-Klerx, P. Sterrenburg, S. M. van Ruth, I. M. J. Scholtens-Toma and E. J. Kok. 2012. Halal assurance in food supply chains: Verification of halal certificates using audits and laboratory analysis. Trends in Food Sci Tech. 27:109-119.

Zhang, C. 2013. Semi-nested multiplex PCR enhanced method sensitivity of species detection in further-processed meats. Food Control. 31: 326-330. 